\title{
Kombinasi Beberapa Dosis dan Spesies Trichoderma Formulasi Pelet Dalam Menekan Perkembangan Jamur Fusarium oxysporum f.sp capsici di Pembibitan Cabai
}

\author{
Merah(Capsicum annum L.) \\ Combination of Several Doses and Species of Trichoderma Pellet Formulations \\ In Suppressing Development Fungus of fusarium oxysporum f.sp capsici \\ in Red Chili Breeding (Capsicum annum L.)
}

\author{
Frara Efeseli Fakhdian ${ }^{1}$, Abduh Ulim ${ }^{1}$, Tjut Chamzurni, ${ }^{2 *}$ \\ ${ }^{1}$ Program Studi Agroteknologi, Fakultas Pertanian, Universitas Syiah Kuala \\ ${ }^{2}$ Program Studi Proteksi Tanaman, Fakultas Pertanian, Universitas Syiah Kuala
}

\begin{abstract}
Abstrak:Cabai merah (Capsicum annum L.) merupakan salah satu komoditas hortikultura unggulan terbesar dari golongan sayur-sayuran karena memiliki harga jual yang tinggi. Disamping itu selain harga yang tinggi, di lapangan cabai merah sering mengalami gangguan dari mulai benih disemai sampai tanaman cabai menghasilkan, hal ini disebabkan penyakit tular tanah atau pun terbawa benih. Salah satu penyakit yang memprihatinkan pada tanaman cabai merah adalah penyakit layu yang disebabkan oleh jamur Fusarium oxysporum f.sp capsici,penyakit ini sering merugikan para petani, jika tanaman sudah terserang oleh penyakitini, kerugian bisa mencapai $80 \%$ pada tanaman cabai merah. Salah satu alternatif yang digunakan dalam Pengendalian Hama dan Penyakit terpadu (PHPT) dengan menggunakan agensia Trichoderma formulasi pelet. Penelitian ini bertujuan agar mengetahui keefektifan Trichoderma Formulasi pelet dalam menekan penyakit Layu Fusarium yang disebabkan oleh Jamur Fusarium oxysporum f.sp capsici. Penelitian ini telah dilaksanakan di laboratorium Penyakit Tumbuhan Program Studi Proteksi Tanaman dan Rumah Kasa Kebun Percobaan Fakultas Pertanian Unsyiah. Penelitian ini dimulai sejak bulan Agustus sampai Oktober 2017. Penelitian ini menggunakan Rancangan Acak Lengkap (RAL) pola non faktorial dengan 9 perlakuan dan 3 ulangan setiap perlakuan terdiri dari 5 unit polibag sehingga terdapat 135 unit polibag. Peubah yang diamati meliputi masa inkubasi, tinggi tanaman, jumlah daun dan persentase serangan.Hasil penelitian menunjukkan bahwa aplikasi pelet Trichoderma harzianum 2,5 g/polibagdan Trichoderma virens $2 \mathrm{~g} / \mathrm{polibag}$ mampu memperlama masa inkubasi (Tidak terdapat gejala). Aplikasi pelet $T$. virens $1,5 \mathrm{~g}$ polibag dapat meningkatkan tinggi tanaman cabai merah sampai $16,80 \mathrm{~cm}$. Aplikasi pelet $T$. harzianum $1,5 \mathrm{~g} /$ polibag dapat mamacu pertumbuhan jumlah daun sebesar 9,07 helai. Aplikasi pelet T. harzianum 2,5 g/polibag dan T. virens formulasi pelet $2 \mathrm{~g} /$ polibag mampu menekan persentase serangan jamur Fusarium oxysporum f.sp capsici sebesar 13,68 \% pada 35 (HST).
\end{abstract}

Kata Kunci : Cabai Merah, Dosis dan Spesies Trichoderma Formulasi Pelet.

Abstract : a red chili (Capsicum annum L.) is one of the largest superior horticultural commodity of vegetables, because it has a high selling price. Although it has high price, but in the field red chilli often disturbance from the seed sowing until the pepper plants produce, it is cause by soil contagion or even carried by seed. One of the most common diseases in red chili plants is the wilting disease cause of the fungus Fusarium oxysporum f.sp capsici. It often detrimental of the farmers if the plants have been attacked by Fusarium wilt disease, the loss could reach out about $80 \%$ in red chili plants. One of the alternative to Integrated Pest and Disease Control (PHPT) is using the Trichoderma pellet formulation agent. The reasearch purpose to determine of the effectiveness Trichoderma Formulation of pellets in suppressing Fusarium Lung disease caused by Fusarium oxysporum f.sp capsici. The research has been conducted in Plant Disease Laboratory of Plant Protection Study Program and home srceen Experimental Garden of Agriculture Faculty Unsyiah. The research was started since August to October 2017. The research uses Completely Randomized Design (RAL) non factorial pattern with 9 treatments and 3 replications each treatment consists of 5 units of polybags so that there are 135 units of polybags. The variable observed included incubation period, plant height, number of leaves and percentage of attacks. Results of the research showed that the application of Trichoderma harzianum pellet $2.5 \mathrm{~g} /$ polybag and Trichoderma virens $2 \mathrm{~g} /$ polybag was able to prolong the incubation period. Application of T. virens pellet $1.5 \mathrm{~g}$ polybags can increase the height of red pepper plants up to $16,80 \mathrm{~cm}$. Application of pellets $T$. harzianum $1.5 \mathrm{~g} /$ polybags can spure growth of leaves amounted to 9.07 strands. The application of $T$. harzianum pellet $2.5 \mathrm{~g} /$ 
polybag and $T$. virens pellet $2 \mathrm{~g} /$ polybag formulation was able to suppress the percentage of Fusarium oxysporum f.sp capsici attack by $13.68 \%$ at 35 days after planting.

Keyword:Chili Red, Dosage and Species Trichoderma Pellet Formulations.

\section{PENDAHULUAN}

Cabai merah (Capsicum annum L.) merupakan salah satu komoditas hortikultura unggulan terbesar dari golongan sayur-sayuran karena memiliki harga jual yang tinggi dan memiliki beberapa manfaat untuk kesehatan diantaranya yaitu sumber kalori, protein, lemak, karbohidrat, kalsium, vitamin A, B1 dan vitamin C. Masyarakat umumnya menggunakan cabai merah sebagai bahan baku keperluan rumah tangga, selain itu cabai merah juga dapat digunakan untuk keperluan industri seperti industri makanan dan industri obat-obatan (Agung, 2007).

Data statistik provinsi Aceh menunjukkan pada tahun 2014 luas areal panen cabai merah maksimal mencapai 128.734 ha dengan tingkat produksi 1.074 .602 ton dan produktivitasnya mencapai 8,35 ton ha $^{-1}$ tahun ${ }^{-1}$, pada tahun 2015 mengalami penurunan luas areal panen cabai merah nasional mencapai 120.847 ha dengan tingkat produksi mencapai 1.045.200 ton, namun produktivitasnya meningkat $8.65{\text { ton } \mathrm{ha}^{-1} \text { tahun }}^{-1}$, sedangkan pada tahun 2016 mengalami peningkatan luas areal panen cabai merah nasional mencapai 123.404 ha dengan tingkat produksi mencapai 1.045 .587 ton, namun, produktivitasnya mengalami penurunan 8.47 ton ha $^{-1}$ tahun $^{-1}$ (BPS dan Ditjen Hortikultura Deptan, 2017).

Salah satu kendala menurunnya produksi cabai adalah adanya gangguan penyakit layu Fusarium yang dapat menyerang sejak dipersemaian sampai tanaman dipanen (Agrios, 2005). Berdasarkan hal tersebut, maka perlu dicari alternatif pengendalian patogen penyebab penyakit yang ramah lingkungan, dengan memanfaatkan potensi mikroorganisme sebagai pengendali hayati terhadap patogen penyebab penyakit layu Fusarium. Gejala permulaan yang ditimbulkan oleh serangan jamur $F$. oxysporum f.sp capsici adalah tulang daun pucat terutama daun bagian bawah, kemudian diikuti merunduknya batang dan akhirnya tanaman menjadi layu secara keseluruhan (Semangun, 2007). Kelayuan sering kali diikuti dengan klorosis daun, terutama pada tanaman muda, dan dapat menyebabkan tanaman mati. Sastrahidayat (1990) menyatakan bahwa $F$. oxysporum f.sp capsici dapat bertahan lama dalam tanah, sehingga tanah yang sudah terinfeksi sukar dibebaskan kembali dari jamur ini.

Beberapa penelitian menunjukkan isolat Trichoderma sp. efektif mengendalikan penyakit layu Fusarium pada tanaman pisang (Thangavelu, Palaniswami, dan Valazahahan, 2003). Menurut Talanca et al, (2003) aplikasi jamur T. harzianum seminggu sebelum inokulasi patogen Fusarium sp. dapat menekan intensitas serangan penyakit busuk batang jagung. Menurut (Zikriah 2016) formulasi dedak + daun katuk merupakan formulasi pelet terbaik untuk $T$. harzianum, dibandingkan formulasi pelet dedak + daun lamtoro, dedak + ampas Tahu, dan dedak saja. Menurut Hajieghrari et. al.,(2008), T. harzianum, T. viridae, T. virens, T. hamatum, T. roseum dan $T$. koningii merupakan spesies yang sering digunakan sebagai agen pengendalian hayati. Beberapa Trichoderma asal tanaman kakao yaitu T.virens, $T$. asperellum dan $T$. longichiatum, telah berhasil diisolasi dipertanaman kakao di Aceh (Sriwati et al., 2015).

Dari permasalahan tersebut diatas maka perlu diketahui kombinasi beberapa dosis dan spesies Trichoderma formulasi pelet terhadap perkembangan jamur $F$. oxysporum f.sp capsici pada pembibitantanaman cabai merah (Capsicum annum L.).

Kombinasi Beberapa Dosis dan Spesies Trichoderma Formulasi Pelet Dalam Menekan Pekembangan Jamur Fusarium oxysporum f.sp capsici Di Pembibitan Cabai Merah (Capsicum annum L.)(Frara Efsesli Fakhdian, 


\section{METODE PENELITIAN}

Penelitian dilaksanakan di Laboratorium Penyakit Tumbuhan Program Studi Proteksi Tanaman dan Rumah Kasa Fakultas Pertanian Universitas Syiah Kuala, dimulai bulan Agustus-Oktober 2017.

Alat yang digunakan dalam penelitian ini adalah gelas ukur, ayakan, erlemeyer, autoclaf, timbangan analitik, inkubator, pisau skapel, lampu bunsen, cawan petri, meteran, laminar air flow, baskom, oven, alat dokumentasi dan alat tulis.

Bahan yang digunakan dalam penelitian ini adalah benih cabai merah varietas Lado, tanah, pupuk kandang, isolat penyakit layu Fusarium oxysporum f.sp capsici didapat dari BALITSA Bandung, Trichoderma harzianum dan Trichoderma virens yang merupakan koleksi dari Laboratorium Penyakit Tumbuhan Program Studi Proteksi Fakultas Pertanian Universitas Syiah Kuala, PDA (Potato Dextrose Agar), beras, aquades, spritus, plastic warp, kantong plastik, aluminium foil, alkohol, polibag volume $200 \mathrm{~g}$, tissue, kertas label dan kapas.

Pelaksanaan Penelitian

Peremajaan dan Perbanyakan Cendawan Fusarium oxysporum f.sp capsici

Biakan murni isolat $F$. oxysporum f.sp capsici yang digunakan merupakan koleksi dari BALITSA Bandung. Kemudian isolat diremajakan dan diperbanyak pada media beras selama 1 bulan.

\section{Trichoderma harzianum dan Trichoderma virens}

Isolat T.harzianum dan T. virens yang digunakan merupakan koleksi dari Laboratorium Penyakit Tanaman Program Studi Proteksi Tanaman Fakultas Pertanian Unsyiah, selanjutnya isolat diperbanyak secara aseptik dengan mengambil sebagian kecil dengan menggunakan pisau skalpel lalu dipindahkan pada cawan petri yang berisi media PDA, kemudian disimpan di dalam inkubator selama 5 hari pada suhu ruang $\left(25^{\circ} \mathrm{C}\right)$.

\section{Pembuatan dan Persiapan Pelet Berbahan Aktif Trichoderma harzianum dan Trichoderma virens}

Bahan dasar yang digunakan dalam pembuatan pelet yaitu, ampas tahu, dedak, molase dan air steril. Tepung didapatkan dari ampas tahu yang sudah dijemur dan diblender kemudian diayak dengan ayakan ukuran 6 mess. Selanjutnya dedak ditimbang sesuai dengan komposisi yang telah ditentukan. Kemudian adonan dibuat dengan cara mencampurkan dedak $31,0 \mathrm{~g}$, tepung ampas tahu 10,5 g, molase sebanyak $15 \mathrm{ml}$ dan air steril $42 \mathrm{ml}$ ditambahkan ke dalam adonan serta diaduk hingga semua bahan homogen, lalu dimasukkan ke dalam plastik tahan panas dan disterilisasi dengan autoklaf dengan suhu $121^{\circ} \mathrm{C}$ selama 30 menit, setelah adonan dingin, lalu isolat $T$. harzianum dan T. virens yang telah diinkubasikan selama 5 hari pada media PDA dibuat suspensi sebanyak $2 \mathrm{ml}$. Kemudian diaduk agar semua campuran menjadi homogen dan adonan dimasukkan ke dalam alat cetakan. Setelah adonan dicetak, dimasukkan kedalam amplop dari kertas buram yang telah disterilkan, dan selanjutnya diinkubasi dalam oven pada suhu $30{ }^{\circ} \mathrm{C}$ selama 48 jam hingga adonan tersebut kering Persiapan Media Tanam.

\section{Persiapan Media Tanam}


Media tanaman yang digunakan pada penelitian ini merupakan tanah (top soil) dari jenis entisol dan pupuk kandang yang diperoleh dari Lambaro Angan Kabupaten Aceh Besar. Tanah tersebut terlebih dahulu dibersihkan dari sisa-sisa tanaman, kemudian tanah tersebut dikering anginkan selama 15 hari. Selanjutnya tanah diayak dan dimasukkan ke dalam polibag volume $200 \mathrm{~g}$. Tanah danpupuk kandang dengan perbandingan 1:1.

\section{Aplikasi Pelet Trichoderma harzianum dan Trichoderma virens}

Aplikasi T. harzianum dan T. viren dilakukan dengan cara membenamkan pelet ke dalam tanah sesuai dengan dosis dan spesies Trichoderma yang diuji. pengaplikasian diberikan 7 hari sebelum tanam. Dosis yang digunakan adalah 0 g/polibag, $1 \mathrm{~g} /$ polibag, 1,5 g/polibag, $2 \mathrm{~g} /$ polibag, 2,5 g/polibag.

\section{Inokulasi PatogenFusarium oxysporum f.sp capsici}

Aplikasi jamur F. oxysporum f.sp capsici dilakukan dengan cara membenamkan ke dalam media tanah yang akan ditanami cabai. Selanjutnya jamur F. Oxysporum f.sp capsici dimasukkan ke dalam lubang dengan kedalaman $3 \mathrm{~cm}$ sebanyak $1 \mathrm{~g}$ substrat per tanaman. Pengaplikasian $F$. oxysporum f.sp capsici dilakukan 5 hari setelah aplikasi Trichoderma.

\section{Penyemaian Benih}

Benih cabai merah yang digunakan adalah varietas Lado. Benih cabai merah direndam dalam air selama 20 menit. Benih yang mengapung dibuang dan benih yang tenggelam digunakan untuk disemai kedalam polybag yang sudah dipersiapkan

\section{Pemeliharaan Tanaman}

Pemeliharaan tanaman meliputi penyiraman, dilakukan dalam dua kali sehari yaitu pada waktu pagi dan sore (tergantung keadaan cuaca). Apabila tumbuh gulma maka dilakukan penyiangan dengan cara mencabut gulma yang tumbuh disekitar tanaman.

\subsection{Peubah yang diamati}

\subsubsection{Masa Inkubasi (hari)}

Masa inkubasi merupakan rentang waktu antara permulaan infeksi dengan timbulnya gejala yang pertama setelah inokulasi patogen. Masa inkubasi diamati sejak inokulasi $F$. oxysporum f.sp capsici sampai muncul gejala awal yaitu warna kuning pada daun paling bawah.

\subsubsection{Tinggi Tanaman $(\mathrm{cm})$}

Pengukuran tinggi tanaman cabai merah dilakukan dengan menggunakan penggaris, pengukuran dilakukan dari pangkal batang sampai titik tumbuh. Waktu pengukuran pada hari ke 7, 14, 21, 28 dan 35 (HST).

\subsubsection{Jumlah Daun (helai)}

Pengamatan jumlah daun dilakukan dengan cara menghitung jumlah daun yang dijumpai. Pengamatan jumlah daun dilakukan pada hari ke 7, 14, 21, 28 dan 35 (HST). 


\subsubsection{Persentase Tanaman Teserang}

Pengamatan persentase tanaman terserang dihitung pada hari ke 7, 14, 21 dan 28 (HST) dengan menggunakan rumus (Finney, 1971)

$$
\mathrm{P}=\frac{a}{b} \times 100 \%
$$

Keterangan

$\mathrm{P}=$ Persentase tanaman terserang,

$\mathrm{a}=$ Jumlah tanaman yang menunjukkan gejala serangan, dan

$\mathrm{b}=$ Jumlah tanaman yang diamati

\section{HASIL DAN PEMBAHASAN}

\subsection{Masa Inkubasi Setelah Inokulasi Patogen}

Pengamatan masa inkubasi dilakukan untuk mengetahui lamanya waktu yang dibutuhkan dari inokulasi patogen sampai timbul gejala pertama. Pengamatan gejala awal ditandai dengan munculnya tanda-tanda serangan penyakit berupa tulang-tulang daun memucat terutama pada daun bawah, kemudian diikuti dengan menggulungnya daun yang tua karena merunduknya tangkai dan akhirnya tanaman layu secara keseluruhan ( Duriatet al., 2007). Dosis pelet $T$. harzianum berpengaruh terhadap masa inkubasi. Hal ini disebabkan karena dosis pelet $T$. harzianumdapat menghambat perkembangan pathogen $F$. oxysporum $f . s p$ capsici pada bibit tanaman cabai. Adapun rata-rata masa inkubasi patogen $F$. oxysporum f.sp capsici yang menginfeksi bibit cabai merah akibat perlakuan dosis pelet $T$. harzianum dan $T$. virens dapat dilihat pada Tabel 2 .

Tabel 1. Rata-rata Masa Inkubasi Tanaman cabai merah setelah Inokulasi Patogen Fusarium oxysporum f.sp capsici.

\begin{tabular}{|c|c|}
\hline Perlakuan & Hari \\
\hline Tanpa pelet Trichoderma & 1 \\
\hline Trichoderma harzianum $1 \mathrm{~g} /$ polibag & 9,53 \\
\hline Trichoderma virens $1 \mathrm{~g}$ / polybag & 4,2 \\
\hline Trichoderma harzianum 1,5 g/ polibag & 5,33 \\
\hline Trichoderma virens $1,5 \mathrm{~g} /$ polybag & 7,5 \\
\hline Trichoderma harzianum $2 \mathrm{~g} /$ polybag & 4,67 \\
\hline Trichoderma virens $2 \mathrm{~g} /$ polybag & Tidak ada gejala. \\
\hline Trichoderma harzianum 2,5 g/ polibag & Tidak ada gejala. \\
\hline Trichoderma virens $2,5 \mathrm{~g} /$ polybag & 3,17 \\
\hline Rerata & 5,08 \\
\hline
\end{tabular}

Tabel 2 menunjukkan bahwa, rata-rata masa inkubasi tercepat dijumpai pada perlakuan tanpa pelet Trichoderma dengan rata-rata masa inkubasi 1,00 hari, kemudian diikuti oleh perlakuan $T$. virens $2,5 \mathrm{~g} /$ polibag dengan rata-rata 3,17 hari sedangkan masa inkubasi terlama dijumpai pada perlakuan $T$. virens $2 \mathrm{~g} /$ polibag dan perlakuan $T$. harzianum 2,5 g/ polibag dimana pada perlakuan tersebut tidak terdapatnya tanda-tanda gejala penyakit layu Fusarium. Data di atas menunjukkan bahwa perlakuan T. virens $2 \mathrm{~g} /$ polibag dan 
perlakuan T. harzianum 2,5 g/ polibag, didapatkan hasil lebih baik dibandingkan dengan masa perlakuan lainnya dalam menghambat perkembangan patogen pada bibit cabai merah. Perbedaan masa inkubasi tersebut diduga karena pengaruh hiperparasitisme $T$. harzianumdanT. Virens sehingga pengaruh dosis $T$. harzianum 2,5g/polibag dan $T$. virens 2g/polibag dapat memperlama masa inkubasi pada tanaman cabai merah.Mahr (2005) menambahkan bahwa Perkembangan $T$. virens sangat cepat. Koloni-koloninya seperti kapas atau benang-benang, dalam seminggu pertumbuhannya akan menutupi keseluruhan permukaan cawan. Jamur ini juga tidak hanya menghasilkan toksin dan antibiotik, tetapi menghasilkan berbagai enzim seperti ekso dan endo glikonase, selulosa dan kitinase.

\subsection{Tinggi Tanaman $(\mathrm{cm})$}

Hasil pengamatan terhadap tinggi tanaman cabai merah. Tinggi tanaman cabai merah berbeda nyata pada hari 7, 14, 21, 28 dan 35 HST akibat perlakuan dosis pelet $T$. harzianum dan $T$. virens formulasi pelet dapat dilihat pada Tabel 3.

Tabel 2. Rata-Rata Tinggi Tanaman cabai merah pada 7,14, 21, 28 dan 35 HST akibat Kombinasi Perlakuan Dosis T. harzianum dan T. virens formulasi pelet Dalam Menekan Jamur Fusarium oxysporumf.spcapsici

\begin{tabular}{|c|c|c|c|c|c|}
\hline \multirow{2}{*}{ Perlakuan } & \multicolumn{5}{|c|}{ Hari ke } \\
\hline & 7 & 14 & 21 & 28 & 35 \\
\hline Tanpa pelet Trichoderma & $\begin{array}{c}0 \\
(0.71) a\end{array}$ & $\begin{array}{c}0 \\
(0.71) a\end{array}$ & $3.10 \mathrm{a}$ & $4.57 \mathrm{a}$ & $3.83 \mathrm{a}$ \\
\hline Trichoderma harzianum $1 \mathrm{~g} /$ polybag & $\begin{array}{c}3.39 \\
(1.96) b\end{array}$ & $\begin{array}{c}5.95 \\
(2.54) c\end{array}$ & $8.36 \mathrm{c}$ & $11.78 b$ & $14.30 \mathrm{~b}$ \\
\hline Trichoderma virens $1 \mathrm{~g} /$ polybag & $\begin{array}{c}3.70 \\
(2.04) b\end{array}$ & $\begin{array}{c}6.54 \\
(2.65) d\end{array}$ & $8.78 \mathrm{c}$ & $12.19 \mathrm{~b}$ & $14.83 b$ \\
\hline Trichoderma harzianum 1,5 g/ polybag & $\begin{array}{c}3.85 \\
(2.08) b\end{array}$ & $\begin{array}{c}6.52 \\
(2.65) d\end{array}$ & $8.75 \mathrm{c}$ & $10.99 b$ & $15.62 b c$ \\
\hline Trichoderma virens $1,5 \mathrm{~g} /$ polybag & $\begin{array}{c}3.44 \\
(1.98) b\end{array}$ & $\begin{array}{c}6.57 \\
(2.66) \mathrm{d}\end{array}$ & $9.13 \mathrm{c}$ & $11.53 \mathrm{~b}$ & $16.80 \mathrm{c}$ \\
\hline Trichoderma harzianum $2 \mathrm{~g} /$ polybag & $\begin{array}{c}3.33 \\
(1.95) b\end{array}$ & $\begin{array}{c}6.05 \\
(2.56) \mathrm{cd}\end{array}$ & $8.65 c$ & $11.05 \mathrm{~b}$ & $12.96 b$ \\
\hline Trichoderma virens $2 \mathrm{~g} /$ polybag & $\begin{array}{c}3.38 \\
(1.96) b\end{array}$ & $\begin{array}{c}5.64 \\
(2.47) b c\end{array}$ & $9.05 \mathrm{c}$ & $12.28 \mathrm{~b}$ & $15.34 \mathrm{bc}$ \\
\hline Trichoderma harzianum 2,5 g/ polybag & $\begin{array}{c}3.17 \\
(1.91) b\end{array}$ & $\begin{array}{c}6.06 \\
(2.56) \mathrm{cd}\end{array}$ & $9.08 \mathrm{c}$ & $12.57 \mathrm{~b}$ & $14.99 \mathrm{~b}$ \\
\hline Trichoderma virens $2,5 \mathrm{~g} /$ polybag & $\begin{array}{c}3.20 \\
(1.91) b\end{array}$ & $\begin{array}{c}5.29 \\
(2.41) b\end{array}$ & $7.39 b$ & $9.92 b$ & $12.07 \mathrm{~b}$ \\
\hline $\mathrm{BNT}_{0.05}$ & 0.18 & 0.18 & 0.78 & 1.13 & 1.47 \\
\hline
\end{tabular}

Keterangan :Angka-angka yang diikuti oleh huruf yang sama pada kolom yang sama tidak berbeda nyata berdasarkan uji BNT pada taraf 5\%. Angka yang berada di dalam ( ) merupakan angka hasil transformasi $\sqrt{\mathrm{x}}+0,5$. 
Berdasarkan Tabel 3 di atas menunjukkan bahwa, rata-rata tinggi tanaman cabai pada perlakuan Tanpa pelet Trichoderma setiap pengamatan menunjukkan hasil yang terendah yaitu $3,83 \mathrm{~cm}$, dan berbeda nyata dengan tinggi tanaman lainnya. Hal ini diduga karena tidak adanya hormon pemacu pertumbuhan dan tidak adanya induksi ketahanan tanaman terhadap patogen yang bisa didapatkan dari agen antagonis, sehingga perkembangan patogen $F$. oxysporum f.spcapsici pada tanaman cabai semakin tumbuh dengan baik. Sedangkan pada perlakuan $T$. harzianum $1 \mathrm{~g} /$ polibag, $T$. virens $1 \mathrm{~g} /$ polibag, $T$. harzianum 1,5 g/ polibag, $T$. harzianum $2 \mathrm{~g} /$ polibag, T. virens $2 \mathrm{~g} /$ polibag, T. harzianum 2,5 g/ polibag dan T. virens 2,5 $\mathrm{g} /$ polibag juga berbeda nyata dengan perlakuan $T$. virens $1,5 \mathrm{~g} /$ polibag. .

Menurut shinshi et al (1987) bahwa zat pengatur tumbuh yang dihasilkan oleh Trichoderma dapat memacu pertumbuhan tanaman dengan baik. Pernyataan Chamzurni et al (2011) yang menyatakan bahwa $T$. harzianum dapat memacu pertumbuhan tanaman dengan menghasilkan hormon auksin dan indole acetic acid (IAA) berperan dalam pemanjangan sesel akar yang menyebabkan serapan hara semakin tinggi, serapan hara yang semakin tinggi memepengaruhi pertumbuhan tanaman karena nutrisi tanaman terpenuhi, sehingga produksi tanaman juga semakin tinggi. Pada hari ke 35 HST perlakuan dengan dosis pelet $T$. virens 1,5 $\mathrm{g} /$ polibag merupakan perlakuan pertumbuhan tinggi tanaman yang paling baik yaitu $16.80 \mathrm{~cm}$.

\subsection{Jumlah Daun (helai)}

Hasil pengamatan terhadap jumlah daun tanaman cabai merah. Jumlah daun yang terbentuk akibat pemberian dosis spesies Trichoderma formulasi pelet dalam menekan perkembangan jamur Fusarium oxysporum f.sp capsici berbeda nyata pada pengamatan 7, 14, 21, 28 dan 35 HST.

Tabel 3. Rata-Rata Jumlah Daun Tanaman cabai merahpada 7, 14, 21, 28, dan 35 HST akibat Kombinasi Perlakuan Dosis dan spesies T. harzianum dan T. virens Formulasi peletdalam Menekan Jamur Fusarium oxysporumf.spcapsici

\begin{tabular}{|c|c|c|c|c|c|}
\hline \multirow{2}{*}{ Perlakuan } & \multicolumn{5}{|c|}{ Hari ke } \\
\hline & 7 & 14 & 21 & 28 & 35 \\
\hline Tanpa pelet Trichoderma & $\begin{array}{c}0 \\
(0.71) \mathrm{a}\end{array}$ & $\begin{array}{c}0 \\
(0.71) \mathrm{a}\end{array}$ & $2.00 \mathrm{a}$ & $2.00 \mathrm{a}$ & $2.00 \mathrm{a}$ \\
\hline Trichoderma harzianum $1 \mathrm{~g} /$ polibag & $\begin{array}{c}2.67 \\
(1.77) \mathrm{b}\end{array}$ & $\begin{array}{c}3.8 \\
(2.07) \mathrm{b}\end{array}$ & $4.67 \mathrm{c}$ & $6.62 \mathrm{c}$ & $7.58 \mathrm{bc}$ \\
\hline Trichoderma virens $1 \mathrm{~g} /$ polybag & $\begin{array}{c}2.67 \\
(1.77) \mathrm{b}\end{array}$ & $\begin{array}{c}3.87 \\
(2.09) b \mathrm{bc}\end{array}$ & $4.72 \mathrm{c}$ & $6.69 \mathrm{c}$ & $8.12 \mathrm{bc}$ \\
\hline Trichoderma harzianum $1,5 \mathrm{~g}$ / polibag & $\begin{array}{c}2.67 \\
(1.76) \mathrm{b}\end{array}$ & $\begin{array}{c}3.93 \\
(2.11) \mathrm{c}\end{array}$ & $4.87 \mathrm{~d}$ & $7.43 \mathrm{~d}$ & $9.07 \mathrm{c}$ \\
\hline Trichoderma virens $1,5 \mathrm{~g} /$ polibag & $\begin{array}{c}2.67 \\
(1.76) b\end{array}$ & $\begin{array}{c}4 \\
(2.12) \mathrm{c}\end{array}$ & $4.93 \mathrm{~d}$ & $6.92 \mathrm{~cd}$ & $6.92 \mathrm{~b}$ \\
\hline Trichoderma harzianum $2 \mathrm{~g}$ / polibag & $\begin{array}{c}2 \\
(1.58) b\end{array}$ & $\begin{array}{c}4 \\
(2.12) \mathrm{c}\end{array}$ & $4.52 \mathrm{bc}$ & $5.87 \mathrm{~b}$ & $7.07 \mathrm{~b}$ \\
\hline Trichoderma virens $2 \mathrm{~g} /$ polybag & $\begin{array}{c}2.33 \\
(1.65) \mathrm{b}\end{array}$ & $\begin{array}{c}4 \\
(2.12) \mathrm{c}\end{array}$ & $4.78 \mathrm{~cd}$ & $6.98 \mathrm{~cd}$ & $8.73 \mathrm{c}$ \\
\hline Trichoderma harzianum 2,5 g/ polibag & $\begin{array}{c}2 \\
(1.58) \mathrm{b}\end{array}$ & $\begin{array}{c}3.93 \\
(2.11) \mathrm{c}\end{array}$ & $4.93 \mathrm{~d}$ & $6.93 \mathrm{~cd}$ & $8.20 \mathrm{bc}$ \\
\hline Trichoderma virens $2,5 \mathrm{~g} /$ polibag & $\begin{array}{c}2 \\
(1.58) \mathrm{b} \\
\end{array}$ & $\begin{array}{c}3.8 \\
(2.07) \mathrm{b} \\
\end{array}$ & $4.32 \mathrm{~b}$ & $6.35 b c$ & $6.88 \mathrm{~b}$ \\
\hline BNT $_{0.05}$ & 0.18 & 0.03 & 0.31 & 0.63 & 1.47 \\
\hline
\end{tabular}

Kombinasi Beberapa Dosis dan Spesies Trichoderma Formulasi Pelet Dalam Menekan Pekembangan Jamur Fusarium oxysporum f.sp capsici Di Pembibitan Cabai Merah (Capsicum annum L.)(Frara Efsesli Fakhdian, 
Keterangan :Angka-angka yang diikuti oleh huruf yang sama pada kolom yang sama berbeda nyata berdasarkan uji BNT pada taraf 5\%. Angka yang berada di dalam ( ) merupakan angka hasil transformasi $\sqrt{x}+0,5$

Tabel 4 menunjukkan bahwa rata-rata jumlah daun tanaman cabai pada pengamatan 7 , 14, 21, 28 dan 35 HST. Pada perlakuan tanpa pelet Trichoderma berbeda nyata dengan jumlah daun dengan perlakuan lainnya. Pada perlakuan tanpa pelet Trichoderma semua waktu pengamatan menunjukkan jumlah daun tanaman cabai yang lebih rendah yaitu 2.00 helai dibandingkan dari semua perlakuan lainnya terhadap jumlah daun yang diperoleh. Pada perlakuan $T$. harzianum $1,5 \mathrm{~g} /$ polibag dijumpai menunjukkan jumlah daun terbanyak yaitu 9.07 helai, kemudian diikuti dengan perlakuan $T$. harzianum $1 \mathrm{~g} /$ polibag, T. virens $1 \mathrm{~g} /$ polibag, T. virens $2,5 \mathrm{~g} /$ polibag dan $T$. harzianum $2 \mathrm{~g} /$ polibag yaitu 7,58 helai, 8,12 helai, 8,20 helai, 8,73 helai. Memberikan hasil yang baik terhadap pertambahan daun tanaman bibit cabai pada waktu pengamatan 35 HST. Perlakuan dosis pelet $T$. harzianum 1,5 g/polibag lebih efektif untuk meningkatkan jumlah daun tanaman.

Hal ini diduga bahwa hormon yang terkandung dalam T. harzianum berpengaruh pada saat proses fotosintesis pada saat penbentukan daun. Azamri et al (2011) menyatakan bahwa pemberian Trichoderma. sp dapat meningkatkan jumlah daun, serta mampu meningkatkan kadar klorofil pada daun. Sejalan dengan pendapat Roco dan Perez (2001) bahwa $T$. harzianum mampu menghasilkan asam giberelin, benzyl amino purin (BAP) dan hormon auksin berupa Indole- 3 Acetic Acid (IAA) yang dapat menstimulasi pertumbuhan tanaman. Hanson dan Howell (2004) menambahkan T. virens yang merupakan mikoparasit bertindak sebagai kompetitor yang baik dalam memperebutkan nutrisi, oksigen dan ruang. T. virens menghasilkan antibiotik berupa gliotoksin yang dapat menghambat pertumbuhan cendawan dan bakteri, serta gliovirin dan viridiol yang bersifat fungistatik.

\subsection{Persentase Serangan}

Tanaman cabai yang terserang patogen Fusarium oxysporumf.sp capsici ditandai dengan munculnya tanda-tanda serangan penyakit berupa tulang-tulang daun memucat terutama pada daun bagian bawah, kemudian diikuti dengan menggulungnya daun yang tua karena merunduknya tangkai dan akhirnya tanaman layu secara keseluruhan (Semangun 1996). Hasil pengamatan terhadap presentase serangan yang disebabkan oleh patogen $F$. oxysporumf.sp capsici pada setiap perlakuan. Persentasi serangan pada bibit cabai akibat pemberian dosis spesies Trichoderma formulasi pelet dalam menekan pekembangan jamur $F$. oxysporum f.sp capsici berbeda nyata pada pengamatan 7, 14, 21, 28 dan 35 HST. Dapat dilihat pada gambar dibawah. 


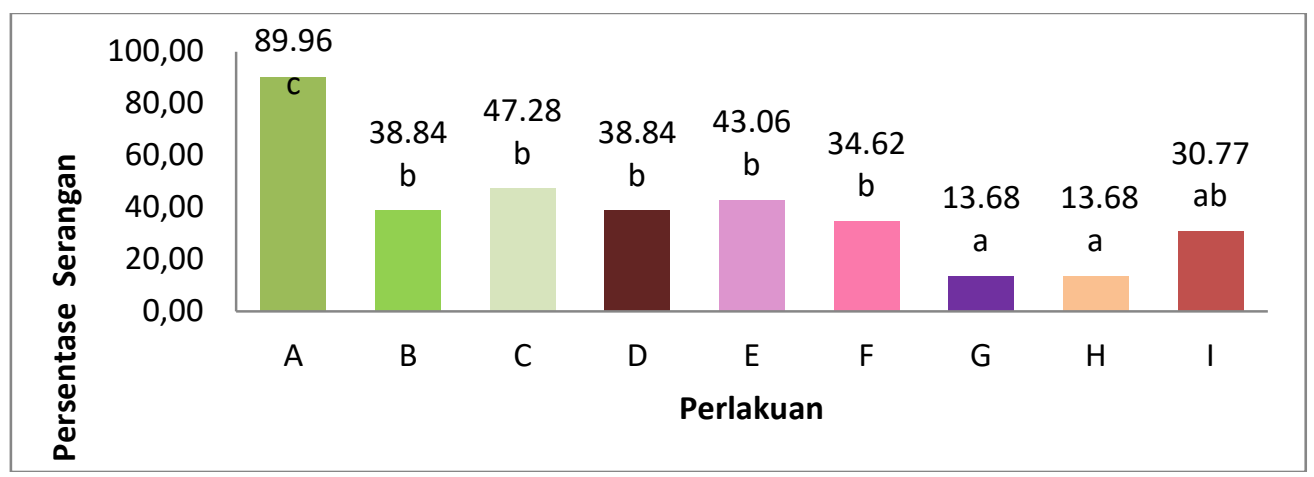

Gambar 1. Rata-rata Persentase Serangan (\%) Patogen F. oxyporum f. sp capsici pada Tanaman cabai merahAkibat Perlakuan Dosis Pelet Berbahan Aktif T. harzianum dan T. viren pada Pengamatan 28 HST. Angka-angka yang diikuti oleh huruf yang sama berbeda sangat nyata pada taraf Uji BNT 5\%. Data ditransformasi Arcsin $\sqrt{X}$. A= Tanpa pemberian pelet, B= TH $1 \mathrm{~g} / \mathrm{polibag}, \mathrm{C}=\mathrm{TV} 1$ g/polibag, D= TH 1,5 g/polibag, E= TV 1,5 g/polibag, F=TH 2 g/polibag, G= TV 2 g/polibag, $\mathrm{H}=$ TH 2,5 g/polibag, I= TV 2,5 g/polibag.

Pada Gambar 1 persentase serangan penyakit berbeda nyata antara perlakuan tanpa pemberian Trichodermadengan perlakuan lainnya, dapat di lihat bahwa persentase serangan penyakit tertinggi terdapat pada perlakuan kontrol tanpa pemberian Trichoderma yaitu 89,96\%. Pada perlakuan dosis pelet T. viren $2 \mathrm{~g} / \mathrm{polibag}$, dosis $T$. harzianum 2,5 g/polibag, menunjukkan persentase serangan yang lebih rendah yaitu $13,68 \%$. Hal ini diduga pada cendawan antagonisTrichoderma mengandung hormon yang dapat mempertahankan diri terhadap serangan penyakit fusarium. Moore (1989) menambahkan bahwa T. harzianum mampu menghasilkan hormon auksin berupa Indole-3 Acetic acid (IAA) yang dapat menstimulasi pertumbuhan tanaman.

\section{KESIMPULAN}

Kombinasi beberapa dosis dan spesies Trichoderma formulasi pelet berpengaruh terhadap masa inkubasi, tinggi tanaman, jumlah daun dan persentase serangan penyakit (Fusarium oxysporum f.sp capsici) dipembibitan cabai merah (Capsicum annum L) pada 35 (HST). Kombinasi dosis dan spesies Trichoderma harzianum 2,5 g/polibag dan Trichoderma virens $2 \mathrm{~g} /$ polibag formulasi pelet berpengaruh terhadap masa inkubasi dan persentase serangan penyakit(Fusarium oxysporum f.sp capsici) dipembibitan cabai merah (Capsicum annum L) pada 35 (HST). Kombinasi dosis dan spesies Trichoderma virens $1,5 \mathrm{~g} / \mathrm{polibag}$ formulasi pelet berpengaruh untuk meningkatkan dan memacu pertumbuhan tinggi tanaman dan Trichoderma harzianum 1,5 g/polibag formulasi pelet berpengaruh untuk memacu jumlah daun dipembibitan cabai merah (Capsicum annum L) pada 35 (HST). Kombinasi dosis dan spesies Trichoderma harzianum dan Trichoderma virens dengan semua dosis yang diuji berpengaruh dalam memperlambat masa inkubasi (Tidak terdapat gejala), meningkatkan tinggi tanaman $(16,80 \mathrm{~cm})$ dan jumlah daun( 9,07 helai), serta menekan persentase serangan penyakit layu (Fusarium oxysporum f.sp capsici)( 13,68\%) dipembibitan cabai merah (Capsicum annum L) pada 35 (HST).

\section{DAFTAR PUSTAKA}

Agrios, G. N. 2005. Plant Pathology. Fifth Edition. Elsevier Aacademic Press, United States of America.

Agung.2007. Budidaya Cabai Merah Pada Musim Hujan. Agromedia Pustaka. Jakarta.

Kombinasi Beberapa Dosis dan Spesies Trichoderma Formulasi Pelet Dalam Menekan Pekembangan Jamur Fusarium oxysporum f.sp capsici Di Pembibitan Cabai Merah (Capsicum annum L.)(Frara Efsesli Fakhdian, 
Azamri, R., G. Hajieghrari and A. Giglou. 2011. Effect of Trichoderma isolates on tomato seedling growth response and nutrient uptake. African Jurnl of Biotechnology. 10(31). 5850-5855.

BPS dan Direktorat Jenderal Hortikultura. 2017. Produksi cabai merah, cabai rawit, dan bawang merah menurut Provinsi Aceh tahun 2014. Badan Pusat Statistik, Aceh.

Duriat, A .S , N. Gunaeni dan A.W. Wulanda. 2007 . Penyakit penting Tanaman Cabai dan pengendaliannya. Balai Penelitian Tanaman Sayuran. Lembang, Bandung. (31) 403991.

Drenth, A. dan Guest. 2004. Diversity and management of Phythopthora in Southeast Asia. J. ACIAR Monograph. 114: 238.

Chamzurni, T., R. Sriwati dan R. D. Selian. 2011. Efektivitas dosis dan waktu aplikasi Trichoderma virens terhadap serangan Sclerotium rolfsii pada kedelai. J .Floratek.6(1):62-67.

Finney, D.J. 1971. Probit Analysis. Cambridge University Press. Cambridge.

Hajieghrari, B., M. Torabi-Giglou, M. R. Mohammadi, and M. Davari. 2008. Biological potential of some Iranian Trichoderma isolates in the control of soil borne plant pathogenic fungi. African Journal of Biotechnology 7 (8) : 967 - 972.

Hanson, L.E., and C.R. Howell. 2004. Elicitors of plant defense responses elisator respon biocontrol strains of Trichoderma virens. Phytopathology. 94(2): Fitopatologi. 94(2): 171-176.

Marh, S. 2005. Gliocladium virens.http://www.entomology.wisc.edu/mben/hyf509.html.[6 Desember 2017].

Moore, T. C. 1989. Biochemistry and Physiology of Plant Hormones. Springer Verlag, New York, Tokyo.

Roco, A and L.M. Perez. 2011. Biocontrol activity of Trichoderma harzianum on Alternaria alternat in presence of growth regulation. J . Biotech. 4(1) : 1-6

Semangun, H. 1996. Ilmu Penyakit Tumbuhan Gajah Mada University Press, Yogyakarta.

Sriwati, R, Chamzurni, C., dan Sukarman. 2011. Deteksi dan identifikasi jamur endofit Trichodermayang berasosiasi pada tanaman kakao. Jurnal Agrista 15(1)

Shinshi, H. D. Mohnen and F.J. Meins. 1987. Regulating of plant pathogenesis-related enzyme; inhibition of chitinase mRNA accumulation in cultured tobacco tissus by auxin and cytokinin. Prceeding National Academy Science. 84:89-93.

Talanca, A. H., W., Wakman and S. Mas'ud. 2003. Pengendalian penyakit busuk batang jagung secara hayati dengan jamur Trichoderma. Proseding Kongres XVII dan Seminar Ilmiah Perhimpunan Fitopatologi Indonesia, 6-8 Agustus 2003. Bandung. 50-54 p

Thangavelu, R., A. Palaniswami, and R. Valazahahan. 2003. Mass production of Trichoderma harzianum for managing Fusarium wilt of banana. J. Agriculture, Ecosystems and Evironment. 103:259-263.

Zikriah. 2016. Potensi daun katuk dan lamtoro sebagai nutrisi cendawan Trichoderma sp.pada pelet media tumbuh dalam menekan pertumbuhan patogen tular tanah. Skripsi. Program Studi Agroteknologi Fakultas Pertanian. Universitas Syiah Kuala, Banda Aceh. 
